\title{
Effects of hypercapnia and hypocapnia on respiratory resistance in normal and asthmatic subjects
}

\author{
F J J van den Elshout, C L A van Herwaarden, H Th M Folgering
}

\begin{abstract}
The effects of hypercapnia and hypocapnia on respiratory resistance were studied in 15 healthy subjects and 30 asthmatic subjects. Respiratory resistance (impedance) was measured with the pseudo-random noise forced oscillation technique while the subjects rebreathed from a wet spirometer in a closed respiratory circuit in which end tidal carbon dioxide tension $\left(\mathrm{PCO}_{2}\right)$ could be controlled. Hypercapnia was induced by partially short circuiting the carbon dioxide absorber, and hypocapnia by voluntary hyperventilation. The circulating air was saturated with water vapour and kept at body temperature and ambient pressure. $A$ rise of end tidal $\mathrm{PCO}_{2}$ of $1 \mathrm{kPa}$ caused a significant fall in respiratory resistance in both normal and asthmatic subjects $(15 \%$ and $9 \%$ respectively). A fall of $\mathrm{PCO}_{2}$ of $1 \mathrm{kPa}$ did not cause any significant change in impedance in the control group. In the asthmatic patients resistance increased by $13 \%$, reactance fell by $45 \%$, and the frequency dependence of resistance rose $240 \%$. These findings confirm that hypocapnia may contribute to airway obstruction in asthmatic patients, even when water and heat loss are prevented.
\end{abstract}

Many specific and non-specific bronchoconstrictor challenges are used to measure bronchial reactivity, including allergens, irritants, cholinergic drugs, mediators, exercise, and hyperventilation. For exercise and hyperventilation challenge respiratory heat loss and increased osmolarity of the airway mucosa are probably the most important factors contributing to bronchoconstriction, ${ }^{1-3}$ though hypocapnia may also contribute. ${ }^{4-6}$ Ventilation is increased in both hypocapnia, when this is induced experimentally by voluntary hyperventilation, and hypercapnia, which stimulates ventilation. The increase in ventilation may obscure the effects of $\mathrm{PCO}_{2}$ on airway resistance, by increasing respiratory heat loss or osmolarity changes.

Acute and chronic airways obstruction in patients with asthma or chronic obstructive lung diseases is often accompanied by hyperventilation. ${ }^{7-10}$ It is still uncertain whether patients with bronchial hyperresponsiveness to histamine are also hyperresponsive to hypocapnia and hypercapnia.

The aim of the present study was to inves- tigate the effect of change in end tidal $\mathrm{PCO}_{2}$ on airway calibre without the confounding effects of heat and water loss from the airway mucosa. The forced oscillation technique was used because the measurements obtained with this method are collected during spontaneous breathing. Forced expiratory manoeuvres, which may influence bronchial tone, ${ }^{11}$ were thus avoided.

\section{Methods}

EQUIPMENT

Oscillatory respiratory resistance (impedance) was measured with the pseudo-random noise forced oscillation technique using the apparatus developed by Landser et al (Oscillaire, Jones, Chicago). ${ }^{12}{ }^{13}$ A loudspeaker generates pressure changes at the mouth in the form of a pseudo-random noise signal containing all harmonics of 4-52 $\mathrm{Hz}$ superimposed on spontaneous breathing. Mouth pressure and flow signals are recorded by two identical differential transducers (Validyne MP 445). Fourier analysis allows the calculation of impedance at $4-52 \mathrm{~Hz}$ from the data, which were collected over eight seconds. The validity of the measurements was evaluated by a coherence function that assessed the amount of noise and alinearity in the signals ${ }^{12}{ }^{14}$; only data with a coherence function of 0.95 or more were retained. The impedance data were subdivided into resistance and reactance and were computed over the range $4-52 \mathrm{~Hz}$ in steps of $4 \mathrm{~Hz}$. Resistance (Rrs), computed as the ratio of the in phase components of pressure and flow, is determined by the resistive properties of the respiratory system (airways, lung tissue, and chest wall). Reactance (Xrs) was computed as the ratio of the components of pressure and flow, which are $90^{\circ}$ out of phase. This part of impedance is determined by the elasticity and mass inertia of the airways, lung tissue, and thorax and the inertia of the air within the bronchi. ${ }^{12-15}$ The variables measured in this study were (1) total respiratory resistance (Rrs) at each frequency tested $(4-8-12 \ldots 52 \mathrm{~Hz})$ and the average value for all frequencies; (2) total respiratory reactance (Xrs) at each frequency tested and the average value for all frequencies; (3) resonant frequency-that is, the frequency at which the reactance is zero; (4) frequency dependence of the resistance, defined in this study as the ratio $(\mathrm{Rrs} 12 \mathrm{~Hz}$ Rrs $52 \mathrm{~Hz}$ )/Rrs $52 \mathrm{~Hz}$.

The Oscillaire apparatus was connected to a wet spirometer (Pulmotest, Godart, De Bitt, Utrecht, Holland) to form a closed respiratory 


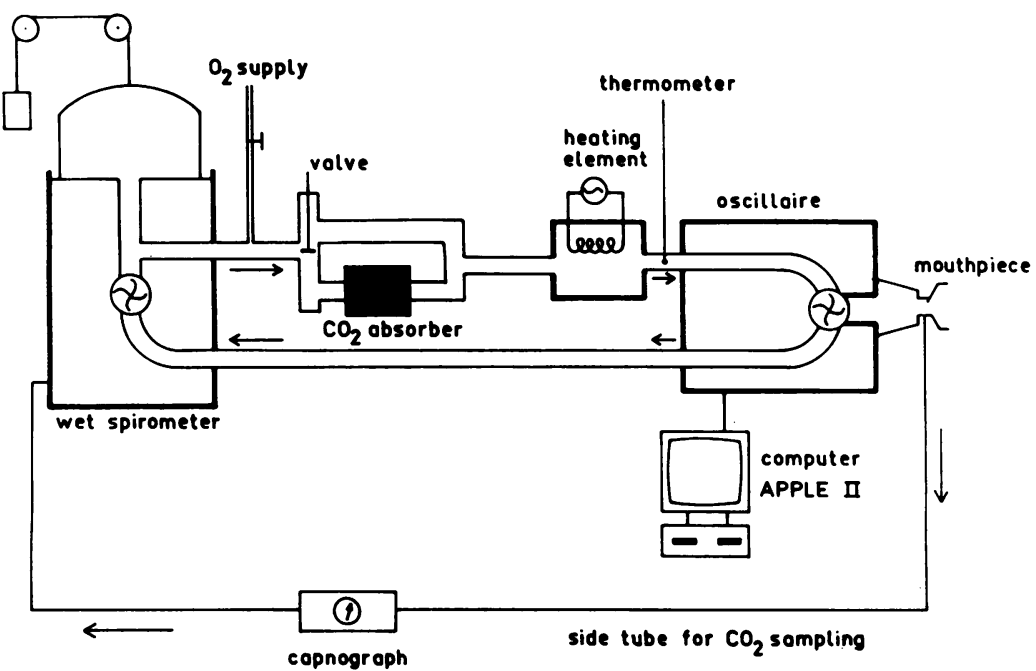

Figure 1 Oscillatory resistance apparatus connected to a wet spirometer to form a closed respiratory circuit to which oxygen was supplied and in which carbon dioxide could be absorbed. circuit to which oxygen was added. Carbon dioxide could be absorbed as desired by partially or totally short circuiting the carbon dioxide absorber. End tidal $\mathrm{PCO}_{2}$ was measured continuously with a rapid infrared analyser (Jaeger,Würzburg, Germany), the sampled air being returned to the closed spirometer circuit. End tidal $\mathrm{PCO}_{2}$ was controlled by changing the fraction of inspiratory air, bypassing the carbon dioxide absorber (fig 1). The air in the respiratory circuit was kept in the BTPS condition. The temperature was maintained at $37^{\circ} \mathrm{C}$ by a heating element and water saturation of air at $90 \%$ or more.

The subjects had their cheeks and submental muscles supported and they wore a nose clip during the impedance measurements.

\section{SUBJECTS}

Forty five subjects were studied: 15 healthy subjects and 30 patients with a history of asthma and bronchial hyperresponsiveness to histamine (the provocative concentration of

Table 1 Characteristics of the subjects (mean (SEM) values unless otherwise specified)

\begin{tabular}{|c|c|c|}
\hline & Normal & Asthmatic \\
\hline Age (y) & $28.0(0.98)$ & $31 \cdot 7(1 \cdot 6)$ \\
\hline $\operatorname{Sex}(F: M)$ & $5: 10$ & $12: 18$ \\
\hline $\mathrm{FEV}_{1}\left(\% \operatorname{pred}^{34}\right)$ & $107 \cdot 2(3 \cdot 4)$ & $85 \cdot 5(3 \cdot 1)$ \\
\hline $\mathrm{MEF}_{50}\left(\%\right.$ pred $\left.^{34}\right)$ & $95 \cdot 6(4 \cdot 5)$ & $52 \cdot 4(3 \cdot 7)$ \\
\hline \multicolumn{3}{|l|}{$\operatorname{Rrs}\left(\mathrm{cm} \mathrm{H}_{2} \mathrm{O} / \mathrm{l} / \mathrm{s}\right)$} \\
\hline At $8 \mathrm{~Hz}$ & $2 \cdot 44(0 \cdot 14)$ & $4.55(0.33)$ \\
\hline At $52 \mathrm{~Hz}$ & $2.94(0 \cdot 19)$ & $4.09(0 \cdot 17)$ \\
\hline Average of frequencies tested & $2 \cdot 65(0 \cdot 15)$ & $4.01(0 \cdot 19)$ \\
\hline $\mathrm{Xrs}$, average $\left(\mathrm{cm} \mathrm{H}_{2} \mathrm{O} / \mathrm{l} / \mathrm{s}\right)$ & $0.89(0.07)$ & $0.87(0.17)$ \\
\hline Resonant frequency $(\mathrm{Hz})$ & $7 \cdot 46(0.39)$ & $16.4(1.65)$ \\
\hline Frequency dependence of the resistance ${ }^{\star}$ & $+0.19(0.02)$ & $-0.01(0.04)$ \\
\hline \multicolumn{3}{|l|}{ Allergy (skin test with 18 allergens: No of subjects) } \\
\hline Any positive result & 0 & 27 \\
\hline Negative results & 15 & 3 \\
\hline \multicolumn{3}{|l|}{ Medication (No of subjects) } \\
\hline Inhaled beta agonist & 0 & 26 \\
\hline Inhaled steroid & 0 & 15 \\
\hline $\mathrm{PC}_{20}$ (mg histamine/ml, geometric mean value) & $>8$ & 0.44 \\
\hline
\end{tabular}

* A negative slope means a decrease in Rrs with increasing oscillatory frequency. FEV 1 - forced expiratory volume in one second; $\mathrm{MEF}_{\text {so }}$-maximal expiratory flow at $50 \%$ of $\mathrm{FEV}$, - forced expiratory volume in one second; MEF 50 -maximal expiratory flow at $50 \%$ or
forced vital capacity; $\mathrm{PC}_{20}$ - concentration of histamine causing a $20 \%$ fall in $\mathrm{FEV}_{1}{ }^{16}$; Rrsoscillatory resistance; $\mathrm{Xrs}-$ reactance. Conversion to $\mathrm{SI}$ units: $1 \mathrm{~cm} \mathrm{H} \mathrm{H} / 1 / \mathrm{s} \approx 0.1 \mathrm{kPa}$. histamine causing a decrease in the forced expiratory volume in one second $\left(\mathrm{FEV}_{1}\right)$ of $20 \%$ or more was less than $\left.8 \cdot \mathrm{mg} / \mathrm{ml}^{16}\right)$. The characteristics of the subjects are shown in table 1 .

The patients used inhaled medication only (beta agonist or corticosteroids or both) and this was discontinued at least eight hours before testing. Patients who had had a respiratory infection in the past six weeks were excluded.

The study was approved by the local ethical committee and informed consent was obtained from all subjects.

\section{PROCEDURE}

To establish whether connecting the spirometer to the Oscillaire changed the measurements, impedance was measured with the Oscillaire alone in 15 subjects (seven healthy subjects and eight patients) and, a few minutes later, with the Oscillaire connected to the wet spirometer circuit. In a further 10 subjects (five healthy subjects and five patients) the humidity of the air in the spirometer circuit was measured continuously during the whole procedure.

All subjects and patients were studied in three different conditions: (1) normocapnic (all carbon dioxide was absorbed in the closed circuit); (2) hypercapnic (with the carbon dioxide absorber partially shortcircuited); (3) hypocapnic (the subjects breathing quietly immediately after one minute of voluntary hyperventilation).

\section{DATA ANALYSIS}

The data from three adequate measurements were averaged for each of the three conditions (hypocapnia, normocapnia, and hypercapnia). The average values of Rrs and Xrs calculated at intervals of $4 \mathrm{~Hz}$ in the range $4-52 \mathrm{~Hz}$ were plotted against the frequency at which they were measured. ${ }^{1213}$ The changes in impedance data from normocapnic (A) to hypercapnic and hypocapnic conditions (B) were calculated for each individual as $[(A-B) /(A)] \times 100 \%$. For statistical analysis Wilcoxon's test for paired observations was used. The differences between the two groups were tested with the Mann-Whitney U test.

\section{Results \\ PRELIMINARY STUDIES}

There were no significant differences between the results obtained with the Oscillaire alone (I) and those obtained with the Oscillaire connected with the wet spirometer circuit (II). The data measured with I and II were compared by means of a two way linear regression analysis and analysis of variance. The coefficient of correlation ranged from 0.94 to 0.98 , with a slope of 0.95 to 1.03 , an intercept of -0.03 to $+0.05(p<0.0001)$. The SE to the regression line varied from 0.02 to $0.06(2-7 \%)$.

The relative humidity of the circulating air was above $90 \%$ within two minutes in the five healthy subjects and five patients when they were breathing in the closed respiratory circuit. 
Table 2 Mean (SEM) values and changes in end tidal carbon dioxide tension $\left(\mathrm{PCO}_{2}\right.$, $k P a$ ) in normocapnic, hypocapnic, and hypercapnic conditions in the two groups of subjects

\begin{tabular}{|c|c|c|c|c|}
\hline & \multicolumn{2}{|l|}{ Normal } & \multicolumn{2}{|l|}{ Asthmatic } \\
\hline & $\mathrm{PCO}_{2}$ & $\Delta \mathrm{PCO}_{2}$ & $\mathrm{PCO}_{2}$ & $\Delta \mathrm{PCO}_{2}$ \\
\hline $\begin{array}{l}\text { Normocapnia } \\
\text { Hypercapnia } \\
\text { Hypocapnia }\end{array}$ & $\begin{array}{l}5 \cdot 3(0 \cdot 18) \\
6 \cdot 4(0 \cdot 23) \\
4 \cdot 2(0 \cdot 19)\end{array}$ & $\begin{array}{l}+1 \cdot 1(0.08) \\
-1.1(0.14)\end{array}$ & $\begin{array}{l}4.8(0.11)^{\star} \\
5.9(0.13) \\
3.8(0.11)\end{array}$ & $\begin{array}{l}+1.0(0.07) \\
-1.0(0.08)\end{array}$ \\
\hline
\end{tabular}

*Significant difference between normal and asthmatic subjects: $p<0.05$ (Mann-Whitney U test).

All further measurements were therefore taken after at least two minutes' closed circuit breathing.

\section{HYPERCAPNIC AND HYPOCAPNIC STUDIES}

During voluntary hyperventilation there was a mean (SEM) increase in functional residual capacity (FRC) of $0.5(0.03) 1$ in the healthy subjects and patients, and this disappeared within two to three breaths of stopping

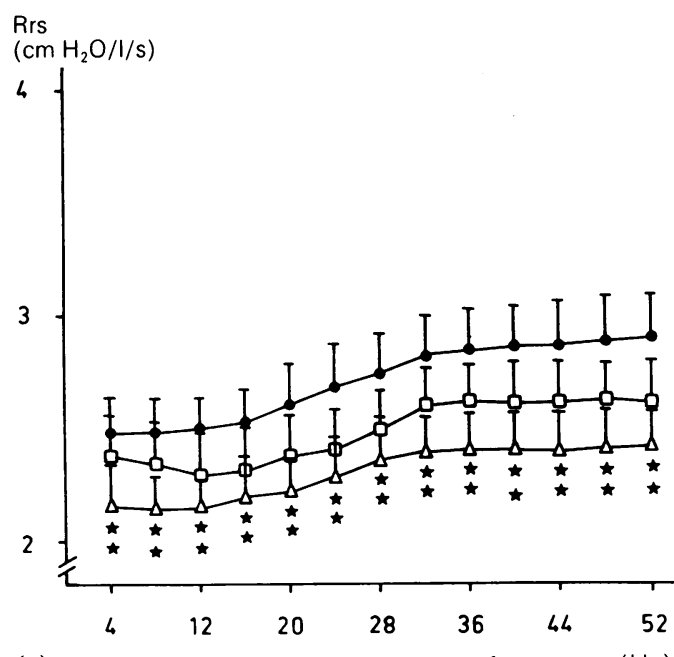

(a)

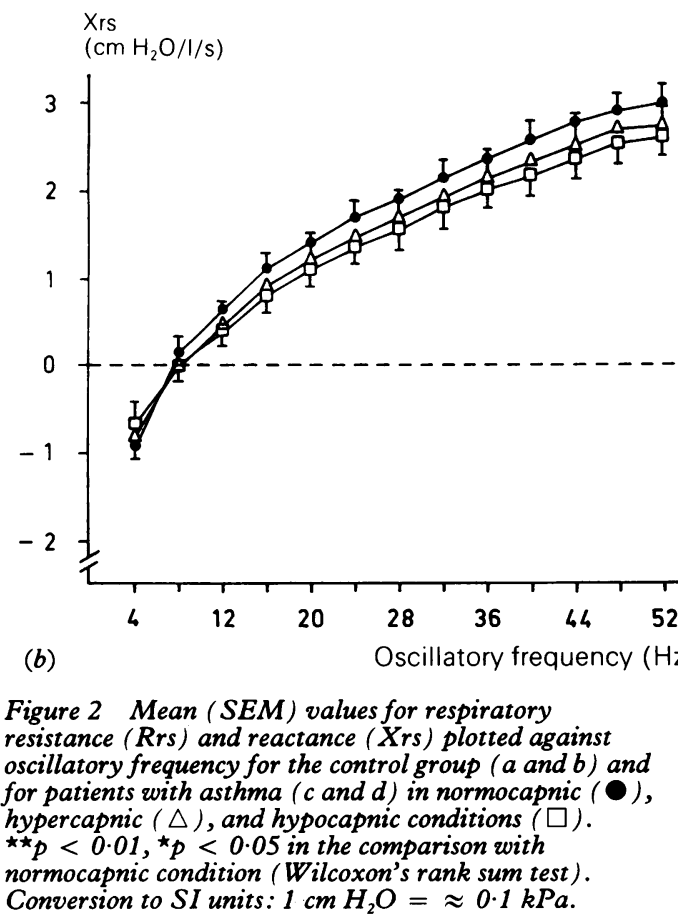

hyperventilation, at a time when end tidal $\mathrm{PCO}_{2}$ was still low. No significant change in FRC was observed during hypercapnia in either group.

The normal subjects had a higher resting end tidal $\mathrm{PCO}_{2}(5.3 \mathrm{kPa})$ than the asthmatic subjects $(5.3 v 4.8 \mathrm{kPa}, \mathrm{p}<0.05$ : table 2). Mean end tidal $\mathrm{PCO}_{2}$ fell by about $1 \mathrm{kPa}$ during hyperventilation and rose by about $1 \mathrm{kPa}$ during rebreathing (table 2). Neither the changes nor the final end tidal $\mathrm{PCO}_{2}$ values differed significantly between the two groups.

In the control group all the resistance values fell during hypercapnia (fig $2 a$, table 3 ). The other impedance results did not change significantly during hypercapnia or hypocapnia (figs $2 a$ and $2 b$, table 3 ).

In the patients hypercapnia also caused a significant decrease in resistance measured at 4-20 Hz (fig 2c). The increase in reactance (table 3) and the changes in the other impedance data (resonant frequency and frequency dependence of resistance) were not significant. Hypocapnia induced an increase in

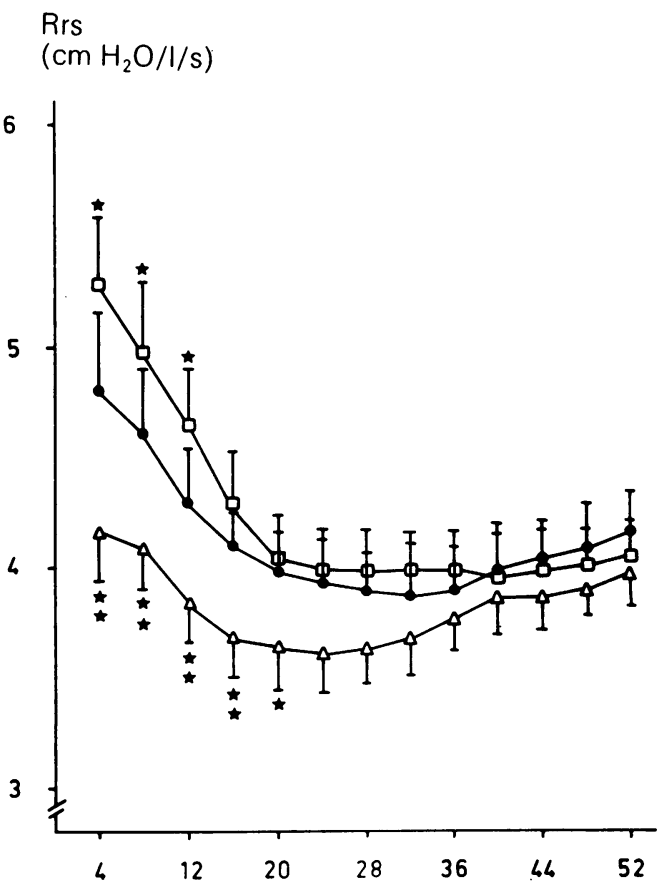

(c) Oscillatory frequency $(\mathrm{Hz})$

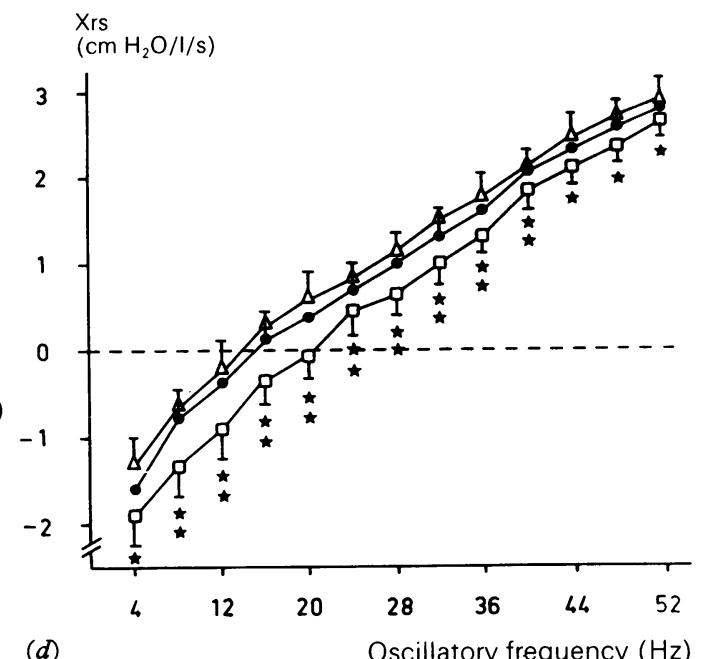


Table 3 Mean (SEM) changes in resistance measured at $8 \mathrm{~Hz}$ (Rrs 8 ) and mean reactance for all frequencies (Xrs (av)) in asthmatic patients and normal subjects during hypercapnia and hypocapnia

\begin{tabular}{llllll}
\hline & Hypercapnia & & & Hypocapnia & \\
\cline { 2 - 3 } \cline { 5 - 6 } & Normal & Asthmatic & & Normal & Asthmatic \\
\hline Rrs8 & $-14 \cdot 6 \%(4 \cdot 8)^{\star \star \star}$ & $-9 \cdot 3 \%(2 \cdot 8)^{\star \star \star}$ & $-1 \cdot 7 \%(6 \cdot 7)$ & $+13 \cdot 2 \%(4 \cdot 2)^{\star \star \star}$ \\
Xrs (av) & $-13 \cdot 3 \%(7 \cdot 0)$ & $+21 \cdot 3 \%(8 \cdot 6)$ & $+0 \cdot 3 \%(15 \cdot 8)$ & $-45 \cdot 5 \%(22 \cdot 1)^{\star \star}$
\end{tabular}

Significance according to Wilcoxon's test: ${ }^{\star \star} p<0.01 ;{ }^{\star \star} p<0.02$, in the comparison with the normocapnic condition. reactance values at all frequencies and the average value confirmed the presence of increased airway obstruction. ${ }^{14}$ The frequency dependence of resistance (a decrease in resistance with increasing frequency) is thought to indicate peripheral airway obstruction. ${ }^{29}$ Frequency dependence was enhanced in our patients, which suggests that hypocapnia causes peripheral airway narrowing in patients with asthma.

Hypocapnia, achieved by hyperventilation or by occlusion of the pulmonary artery, may cause bronchoconstriction by vagal reflex pathways or by a direct effect on bronchial smooth muscle. Hypocapnia caused increased activity of both the slowly adapting stretch receptors and the irritant receptors in anaesthetised dogs, and airway calibre consequently decreased. These effects were reversed by the administration of carbon dioxide, which resulted in reflex bronchodilation. ${ }^{30}{ }^{31}$ Several investigators have shown that carbon dioxide tension in the airway rather than in tissue or blood was the stimulus. ${ }^{31} 32$

In dogs a decrease in end tidal $\mathrm{PCO}_{2}$ of nearly $2 \mathrm{kPa}$ after pulmonary arterial occlusion caused an increase in resistance of about $20 \%$ and fall in compliance of $18 \%$. Vagotomy diminished the increase in resistance but did not affect the fall in compliance, which suggests a direct smooth muscle effect. ${ }^{31}$ These results are in keeping with our finding of an increase in resistance of $13 \%$ due to a fall in $\mathrm{PCO}_{2}$ of $1 \mathrm{kPa}$.

We conclude that hypercapnia decreases airway resistance measured by the forced oscillation technique in both healthy and asthmatic individuals. Hypocapnia appeared to increase both central and peripheral airway resistance in the asthmatic patients but not in the healthy subjects. These results suggest that an enhanced response to hypocapnia (and hypercapnia) is a component of bronchial hyperresponsiveness in asthmatic patients. Hypocapnia, which occurs in an early stage of an asthmatic attack as a result of hyperventilation, ${ }^{1033}$ is an additional stimulus for bronchoconstriction, independent of drying and cooling of the airways.

The authors gratefully acknowledge the financial support of Glaxo BV, The Netherlands, and the valuable advice of $\mathrm{Dr} F$ Landser, Leuven, Belgium, and Dr J W Lammers, Nijmegen, The Netherlands. ensitive and reproducible indices of change airway diameter in bronchial challenge tests or in chronic airways obstruction. ${ }^{142122}$ The central chemoreceptors of the medulla are thought to play a part in the reflex constriction and relaxation of the airways. ${ }^{23}$ Reported direct effects of hypercapnia on airway calibre have been contradictory, increased resistance, ${ }^{24} 25$ decreased resistance, ${ }^{26}$ and no effect ${ }^{27}$ all having been described. Hypercapnia possibly decreases bronchial muscle contractility directly. Hypercapnic acidosis has been found to cause a reduction in bronchial (but not tracheal) muscle contractility in the isolated bronchus of the dog. ${ }^{28}$

A reduction in end tidal $\mathrm{PCO}_{2}$ of $1 \mathrm{kPa}$ by voluntary hyperventilation caused no significant changes in impedance in the control group. In the asthmatic subjects resistance at $4-12 \mathrm{~Hz}$ rose. The concomitant decrease in the
1 Hahn A, Anderson SD, Morton AR, Black JL, Fitch KD. A reinterpretation of the effect of temperature and water content of the inspired air in exercise-induced asthma. $\mathrm{Am}$ Rev Respir Dis 1984;130:575-9.

2 Kilham J, Tooley M, Silverman M. Runnning, walking and hyperventilation causing asthma in children. Thorax 1979;34:582-6.

3 Deal CE Jr, McFadden ER Jr, Ingram RH Jr, Jaegher JJ. Hyperpnea and heat flux: initial reaction sequence in Hyperpnea and heat flux: initial reaction sequence in
exercise induced asthma. $J$ Appl Physiol: Respirat Environ exercise induced asthma.
Physiol 1979;46:476-83.

4 Newhouse MT, Becklake MR, Macklem PT, McGregor M. Effect of alterations in end tidal $\mathrm{CO}_{2}$ tension on flow resistance. J Appl Physiol 1964;19:745-9.

5 Sterling GM. The mechanism of bronchoconstriction due to hypocapnia in man. Clin Sci 1968;34:277-85.

6 Cutillo A, Omboni E, Perondi R, Tana F. Effect of hypocapnia on pulmonary mechanics in normal subjects hypocapnia on pulmonary mechanics in normal subjects
and in patients with chronic obstructive lung disease. $\mathrm{Am}$ and in patients with chronic obs

7 Oliven A, Cherniack NS, Deal CE, Kelsen SB. The effects of acute bronchoconstriction on respiratory activity in 
patients with chronic obstructive pulmonary disease. $A m$ Rev Respir Dis 1985;131:236-41.

8 Loveridge B, West P, Anthonissen NR, Krijger MH. Breathing patterns in patients with chronic obstructive pulmonary disease. Am Rev Respir Dis 1984;130:730-3.

9 Lavietes MH. Ventilatory control in asthma. Clin Chest Med 1984;4:607-17.

10 Kesten S, Reza Malecki-Yazdi M, Sanders BR, et al. Respiratory rate during acute asthma. Chest 1990;97: 58-62.

11 Orchek J, Nicoli MM, Delpierre S, Beaupré A. Influence of the previous deep inspiration on the sphirometric measurement of proyoked bronchoconstriction in asthma. Am Rev Respir Dis 1981;123:269-72.

12 Landser FJ, Nagels J, Demedts M, Billiet L, Van de Woestijne KP. A new method to determine frequency characteristics of the respiratory system. J Appl Physiol 1976;41:101-6.

13 Landser FJ, Polko AH, Visser BF. Oscillatory measurement of total repiratory impedance with extended spectrum up to $52 \mathrm{~Hz}$. Arch Internat Physiol Biochem 1983;91:12.

14 Clement J, Landser FJ, Van de Woestijne KP. Tota resistance and reactance in patients with respiratory complaints with and without airways obstruction. Chest complaints with

15 Solymar L, Landser FJ, Duiverman E. Measurement of resistance with the forced oscillation technique. Eur Respir $J$ 1989;2(suppl 4):150-3S

16 Cockcroft DW, Killian DN, Mellon JJ, Hargreave FE Bronchial reactivity to inhaled histamine: a method and clinical survey. Clin Allergy 1977;7:235-43.

17 Van den Elshout FJJ, Van de Woestijne KP, Folgering HThM. Variations of respiratory impedance with lung volume in bronchial hyperreactivity. Chest 1990;98: 358-64

18 Flenley DC. Physiological and pharmacological control of the respiratory drive in asthma. In: Kay $\mathrm{AB}$, Austen $\mathrm{KF}$, Lichtenstein LM, eds Asthma. London: Academic Press, 1984:375-90.

19 Decramer M, Demedts M, Van de Woestijne KP. Isocapnic hyperventilation with cold air in healthy non-smokers, smokers and asthmatic subjects. Bull Eur Physiopathol Respir 1984;20:237-43.

20 Dejaegher Ph, Rochette F, Clarysse I, Demedts M Hypocapnic hyperventilation versus isocapnic hyperventilation with ambient air or with dry air in asthmatics. Eur
J Respir Dis 1987;70:102-9.

21 Duiverman EJ, Neijens HJ, Van der Snee-Van Smaelen M Kerrebijn KF. Comparison of forced oscillometric and forced expirations for measuring dose-related responses to inhaled methacholine in asthmatic children. Bull Eur Physiopathol Respir 1986;22:433-6.

22 Van Noord JA, Clement J, Van de Woestijne KP, Demedts $M$. Total respiratory resistance and reactance as a measurement of response to bronchial challenge with histamine. Am Rev Respir Dis 1989;139:921-6.

23 Deal CE Jr, Haxihiu MA, Norcia MP, Mitra J, Cherniack NS. Influence of the ventral surface of the medulla on trachael responses to $\mathrm{CO}_{2} . J$ Appl Physiol 1986;61:1091-7.

24 Sly PD, Bates JHT, Kochi T, Okubo S, Milic-Emili J. Frequency-dependent effects of hypercapnia on respiratory mechanics of cats. J Appl Physiol 1987;62: $444-50$

25 Green M, Widdicombe JG. The effects of ventilation of dogs with different gas mixtures on airway calibre and lung mechanics. J Physiol Lond 1966;186:363-81.

26 Delpierre S, Jammes Y, Mei N, Mathiot MJ, Grimaud C. Mise en evidence de l'origine vagale reflexe des effets bronchoconstricteurs du $\mathrm{CO}_{2}$ chez le chat. $J$ Physiol Paris 1980;76:889-91.

27 Butler J, Caro CG, Alcala R, Dubois AB. Physiological factors affecting airway resistance in normal subjects and in patients with obstructive respiratory disease. $J$ Clin Invest 1960;39:584-91.

28 Stephens NL, Meyers JL, Cherniack RM. Oxygen, carbon dioxide, $\mathrm{H}^{+}$ion, and bronchial length-tension relationships. J Appl Physiol 1968;25:376-83.

29 Kjeldgaard JM, Hyde RW, Speers DM, Reichert WW. Frequency dependence of total respiratory resistance in early airway disease. Am Rev Respir Dis 1976;114:501-8.

30 Coleridge HM, Coleridge JCG, Banzett RB. Effect of CO on afferent vagal endings in the canine lung. Respir Physiol 1978;34:135-51.

31 Ingram RH Jr. Effects of airway versus arterial $\mathrm{CO}_{2}$ changes on lung mechanics in dogs. $J$ Appl Physiol 1975;38:603-7.

32 Luijendijk SCM. Within-breath $\mathrm{PCO}_{2}$ levels in the airways and at the pulmonary stretch receptor sites. J Appl Physio 1983;55:1333-40

$33 \mathrm{McFadden}$ ER Jr, Lyons HA. Arterial blood gas tension in asthma. N Engl J Med 1968;278:1027-32.

34 Quanjer $\mathrm{Ph} \mathrm{H}$. Standardized lung function testing. Bull Eur Physiopathol Respir 1983;19(suppl 5):1-92. 